NBER WORKING PAPER SERIES

\title{
REDISTRIBUTION IN THE CURRENT U.S. SOCIAL SECURITY SYSTEM
}

\author{
Jeffrey B. Liebman \\ Working Paper 8625 \\ http://www.nber.org/papers/w8625
NATIONAL BUREAU OF ECONOMIC RESEARCH
1050 Massachusetts Avenue
Cambridge, MA 02138
December 2001

\begin{abstract}
An earlier version of this paper was presented at the National Bureau of Economic Research conference on Distributional Aspects of Social Security and Social Security Reform in Woodstock, Vermont on October $23^{\text {rd }}, 1999$. I am grateful to Jeffrey Brown, Don Fullerton, Steven Goss, David Pattison, Andrew Samwick, and Steve Zeldes for discussions about this research, to Joshua Pollet, Ying Qian, Peter Spiegler, and Elizabeth Welty for excellent research assistance, to Henry Aaron, Gary Burtless, Peter Diamond, Martin Feldstein and conference participants for comments on an earlier draft, and to Hugh Richards for providing tabulations from the National Longitudinal Mortality Survey. This research was conducted while the author was also a Census Bureau research associate at the Boston Research Data Center. Research results and conclusions expressed are those of the author and do not necessarily indicate concurrence by the Bureau of the Census. This paper has been screened by a Census Bureau employee to insure that no confidential data is revealed. This research was funded by a grant from the Russell Sage Foundation and by a First Award from the National Institute on Aging. The views expressed herein are those of the authors and not necessarily those of the National Bureau of Economic Research.
\end{abstract}

(C) 2001 by Jeffrey B. Liebman. All rights reserved. Short sections of text, not to exceed two paragraphs, may be quoted without explicit permission provided that full credit, including (C) notice, is given to the source. 
Redistribution in the Current U.S. Social Security System

Jeffrey B. Liebman

NBER Working Paper No. 8625

December 2001

JEL No. H55, I3

\begin{abstract}
Because its benefit formula replaces a greater fraction of the lifetime earnings of lower earners than of higher earnings, Social Security is generally thought to be progressive, providing a "better deal" to low earners in a cohort than to high earners. However, much of the intra-cohort redistribution in the U.S. Social Security system is related to factors other than lifetime income. Social Security transfers income from people with low life expectancies to people with high life expectancies, from single workers and from married couples with substantial earnings by the secondary earner to married one-earner couples, and from people who work for more than 35 years to those who concentrate their earnings in 35 or fewer years.

This paper studies the redistribution accomplished in the retirement portion of the current U.S. Social Security system using a microsimulation model built around a match of the 1990 and 1991 Surveys of Income and Program Participation to Social Security administrative earnings and benefit records. The model simulates the distribution of internal rates of returns, net transfers, and lifetime net tax rates from Social Security that would have been received by members of the 1925 to 1929 birth cohorts if they had lived under current Social Security rules for their entire lives. The paper finds that annual income-related transfers from Social Security are only 5 to 9 percent of Social Security benefits paid, or $\$ 19$ to $\$ 34$ billion, at 2001 aggregate benefits levels, when taxes and benefits are discounted at the cohort rate of return of 1.29 percent. At higher discount rates, Social Security appears to be more redistributive by some measures, and less redistributive by others. Because much of the redistribution that occurs through Social Security is not related to income, the range of transfers received at a given level of lifetime income is quite wide. For example, 19 percent of individuals in the top lifetime income quintile receive net transfers that are greater than the average transfer for people in the lowest lifetime income quintile.
\end{abstract}

Jeffrey B. Liebman

Kennedy School of Government

Harvard University

Cambridge, MA 02138

and NBER

jeffrey_liebman@harvard.edu 
Social Security is the largest income-transfer program in the United States. In 2001 the program is expected to bring in $\$ 532$ billion in (non-interest) revenue, mostly from payroll taxation of current workers, and to pay out $\$ 439$ billion, mostly in benefit checks to retirees. ${ }^{1}$ Because its benefit formula replaces a greater fraction of the lifetime earnings of lower earners than of higher earners, Social Security is generally thought to be progressive, providing a "better deal" to low earners in a cohort than to high earners in the same cohort. In addition, the program is considered to be particularly important in preventing poverty among the lowest income elderly. ${ }^{2}$

A number of proposed Social Security reforms would increase the link between a worker's Social Security contributions and retirement income, replacing or supplementing the current system with a system of defined-contribution personal retirement accounts funded proportionally to earnings. ${ }^{3}$ These proposals have led to concern that the amount of redistribution and poverty alleviation accomplished through Social Security would decline if an individual-account based system were established.

${ }^{1}$ These numbers are for the entire Old-Age, Survivors, and Disability Insurance program (OASDI). The non-disability portion of the program that is the focus of this paper is projected to have (non-interest) income of $\$ 455$ billion and expenditures of $\$ 378$ billion.

${ }^{2}$ Social Security Administration (2000) calculates (ignoring behavioral effects) that without Social Security elderly poverty would rise from 9 percent to 48 percent. Burtless (1994) argues that social insurance programs like Social Security are more important than means-tested transfers in lifting families out of poverty.

3 There is no reason why the individual accounts must be funded proportionally to earnings. Feldstein and Liebman (2002) show that by funding personal retirement accounts with a combination of flat per-worker contributions and proportional contributions, an investmentbased defined contribution system can accomplish as much or more redistribution as the current system. 
However, much of the intra-cohort redistribution in the U.S. Social Security system is related to factors other than income. Social Security transfers income from people with low life expectancies to people with high life expectancies, from single workers and from married couples with substantial earnings by the secondary earner to married one-earner couples, and from people who work for more than 35 years to those who concentrate their earnings in 35 or fewer years. Since high-income households tend to have higher life expectancies and receive larger spouse benefits, some of the progressivity of the basic benefit formula is offset. Understanding the redistribution that occurs through the current U.S. Social Security system is important for assessing the potential costs of moving to a mixed Social Security system incorporating both pay-as-you-go and individual-account components and for designing modifications to the traditional system that could complement other reforms.

The main results in this paper come from a microsimulation model of the retirement portion of Social Security and use a data set which matches the 1990 and 1991 Surveys of Income and Program Participation (SIPP) to Social Security administrative earnings and benefit records. The model simulates the distribution of internal rates of returns, net transfers, and lifetime net tax rates from Social Security that would have been received by members of the 1925 to 1929 birth cohorts if they had lived under current Social Security rules for their entire lives. The results indicate that Social Security provides within-cohort transfers equal to 13 percent of Social Security benefit payments when discounted at the overall cohort rate of return of 1.29 percent. ${ }^{4}$ However, much of the redistribution that occurs through Social Security is not related

${ }^{4}$ More specifically, within-cohort transfers are measured as the present discounted value of Social Security benefits received minus the present discounted value of Social Security taxes paid all discounted at the cohort rate of return. Therefore, someone whose rate of return is greater 
to income, and thus income-related transfers are only 5 to 9 percent of Social Security benefits paid, or $\$ 19$ to $\$ 34$ billion, at 2001 aggregate benefit levels. ${ }^{5}$ At higher discount rates, Social Security appears more redistributive by some measures and less redistributive by other measures.

The paper begins in section 1 by presenting basic data on the annual redistribution that occurs through Social Security, and then reviews, in section 2, the reasons for preferring a lifetime measure of redistribution and the sources of lifetime redistribution in the U.S. Social Security system. Section 3 discusses the simulation model, and section 4 explains the methodology used for measuring lifetime redistribution. Section 5 provides the results on redistribution in the current system, and Section 6 compares my results to those in recent studies by Caldwell et al (1999), Coronado, Fullerton, and Glass (2000), and Gustman and Steinmeier (2000b) and discusses implications of the results for Social Security reform. Section 7 concludes.

\section{Annual Redistribution from Social Security}

Each year, Social Security raises tax revenue from workers and pays out benefits to retirees and other beneficiaries. Table 1 presents estimates from the Current Population Survey (CPS) for calendar year 1998 that describe these annual flows of taxes and benefits for different

than the cohort rate of return receives a positive transfer and someone with a rate of return that is lower than the cohort return receives a negative transfer. Total transfers can be calculated by summing either the positive or negative transfers (which each sum to the same quantity).

${ }^{5}$ As will be explained in detail later, income-related transfers are calculated by assigning each individual a transfer that is the average for the individual's level of income. 
demographic groups. ${ }^{6}$

The first row of the table shows that overall in 1998, Social Security paid out $\$ 375$ billion in benefit payments and raised $\$ 430$ billion in payroll taxes. The ratio of benefits to taxes was therefore 0.87 . Dividing the $-\$ 55$ billion difference between benefits and taxes by the entire U.S. population of 272 million produces a per capita difference of $-\$ 203$.

As would be expected, the gap between benefits received and taxes paid differs substantially across demographic groups. Individuals who are under 18 receive twice much in benefits as they pay in taxes, since few children have labor income while some receive benefits if their parents are disabled or deceased. In contrast, individuals in the prime working years of 30 to 49 years of age receive benefits that are only 8 percent of the taxes they pay. Individuals who are 65 and above receive 30 times as much in benefits as they pay in taxes.

Forty-six percent of Social Security benefits go to people in families whose non-Social Security income is below the poverty line. This result is not surprising since Social Security represents 90 percent or more of income for 30 percent of elderly families and 50 percent or more for 63 percent of elderly families (Social Security Administration, 2000). Total Social Security benefits for females are slightly greater than those for males, as the greater longevity for women outweighs their lower average benefit levels. Due to their higher average level of earnings, men

${ }^{6}$ The CPS measures total OASDI benefits and does not distinguish between retirement and disability benefits. I assume that the full incidence of the OASDI payroll tax is on the worker and estimate OASDI payroll taxes as 12.4 percent of earnings for individuals with a positive value in the CPS FICA variable (individuals with positive earnings and a zero value in the FICA variable are in sectors of the economy not covered by Social Security). I multiply each individual's Social Security benefit by 1.17 and tax payments by 0.984 so that aggregate OASDI benefits and taxes match the levels reported for calendar year 1998 in Board of Trustees of the Federal Old-Age and Survivors and Disability Insurance Trust Funds (2001). 
pay substantially more in Social Security taxes than do women. Thus annual Social Security benefits for men are only 68 percent of taxes paid, while benefits for women are 120 percent of taxes paid.

The ratio of benefits to taxes paid is highest in the South with its disproportionate share of retirees, and lowest in the West with its large share of younger workers including recent immigrants. Similarly, while whites and blacks each receive benefits that are roughly 90 percent of taxes paid, demographic groups such as Asians and Hispanics, which include many recent immigrants and relatively few elderly, pay two to three times as much in taxes as they receive in benefits each year. Finally, individuals with low levels of education receive on average substantially more in Social Security benefits than they pay in taxes, while the reverse is true for individuals in high education groups. This primarily reflects the increase in education levels over time in the U.S. (i.e. elderly Social Security beneficiaries come from cohorts with lower average education levels than do current workers).

\section{Sources of Intracohort Lifetime Redistribution in the U.S. Social Security System}

The results on annual redistribution are interesting since they describe large annual transfers of resources among different demographic groups - transfers that depend mostly on the ratio of beneficiaries to earners within each group. Over a lifetime, however, most individuals transition from earning income and paying OASDI taxes to receiving Social Security benefits. Therefore, taking a lifetime perspective provides a better measure of how the U.S. Social Security system treats different types of individuals.

How a person fares from the Social Security system depends both on how well he or she 
is treated relative to other people in his or her birth cohort and on how well the birth cohort as a whole fares. While this paper focuses on intracohort redistribution, it is important to note that there are interactions between intercohort and intracohort redistribution. In particular, the early cohorts of Social Security beneficiaries received windfalls because they were the initial generations in an expanding pay-as-you-go system and received substantial benefits even though they had paid relatively little in taxes. Because Social Security benefits rise with income, the largest dollar windfalls went to upper-income beneficiaries in these early cohorts. As later cohorts with lower rates of return have retired, the system has become more progressive because the increased payroll tax rates have resulted in higher-income individuals paying substantially more taxes in present-value terms than they receive in benefits. ${ }^{7}$

The fundamental source of intracohort redistribution from Social Security is its progressive benefit formula. While OASDI payroll taxes are proportional to earnings up to a cap that is currently $\$ 80,400$, the benefit formula replaces a higher fraction of lifetime earnings for low earners than high earners. Benefits are calculated by indexing earnings to average wage growth (through the year the worker turns 60), summing the highest 35 years of earnings, and then dividing by 420 ( 35 x 12) to produce a worker's Average Indexed Monthly Earnings (AIME). The worker's Primary Insurance Amount (PIA) - the monthly benefit the worker will receive if he or she retires at the full-benefit age - is currently calculated as 90 percent of the first \$561 of AIME, plus 32 percent of AIME between $\$ 561$ and \$3381, plus 15 percent of any AIME

${ }^{7}$ Burkhauser and Warlick (1981), Hurd and Shoven (1985), Duggan, Gillingham, and Greenlees (1993), and Steuerle and Bakija (1994) show that the higher rates of return earned by early cohorts of Social Security beneficiaries led to net transfers from the system that were often greater for high income individuals. 
above $\$ 3381$.

This basic relationship between AIME and benefit levels is altered by two major factors. First, higher income individuals tend to live longer (Kitagawa and Hauser, 1973; Rogot et al, 1992; Pappas et al, 1993) and therefore receive benefits for more years. ${ }^{8}$ Second, the aged spouse of a retired worker is entitled to a spouse benefit equal to 50 percent of the worker's benefit while the worker is alive and to a survivor benefit equal to the worker's full benefit after the worker dies. These benefits for spouses and survivors imply that Social Security redistributes from single workers to married couples and from men to women. As will be shown later, by some measures they also offset some of the progressivity of the retired worker benefit because spouses of high-earners receive higher spouse benefits than spouses of low-earners. ${ }^{9}$

Additional redistribution occurs to individuals with short spells in covered work such as immigrants and government workers whose AIME's can substantially understate lifetime income. ${ }^{10}$ In contrast, workers with substantial earnings in years outside of their 35 highest years

${ }^{8}$ Aaron (1977), Steuerle and Bakija (1994), and Garrett (1995) present illustrative calculations for hypothetical workers that suggest that this effect can be large. Panis and Lillard (1996) show using microdata that income transfers from whites to blacks and high-income to low-income workers are much smaller once differential mortality is considered. In contrast, Duggan, Gillingham, and Greenlees (1995) analyze mortality patterns in the Continuous Work History Survey and conclude that differential mortality does little to offset the progressivity of Social Security. For comparable research on Medicare, see McClellan and Skinner (1997).

9 Boskin, Kotlikoff, Puffert, and Shoven (1987) present results showing how marital status affects the rates of return from Social Security.

${ }^{10}$ See Gustman and Steinmeier (2000a) for a discussion of Social Security's treatment of immigrants. In theory, the government pension offset and windfall elimination provisions reduce the extent to which workers in non-covered employment receive windfalls from Social Security. In practice, it is often difficult for the Social Security Administration to apply these provisions since workers do not always report their government pension income to the Social Security Administration. 
are not rewarded by Social Security for that work. Finally, to the extent that the rate of wage growth used to index earnings differs from the benchmark interest rate used to calculate redistribution, the timing of earnings through the lifetime can affect the amount of redistribution a worker receives from the system. ${ }^{11}$

\section{Data}

This paper uses a microsimulation model based on a match of individuals in the 1990 and 1991 panels of the Survey of Income and Program Participation to Social Security administrative earnings and benefit records for those same individuals. I select SIPP sample members who were born between 1925 and 1929, and construct lifetime earnings and marital histories from age 21 through age 64 using the administrative records and the SIPP topical module on marriage. I then simulate the sample members' Social Security payroll taxes and benefit levels under current Social Security rules (rather than under the ones they actually experienced).

The strength of the simulation model is that it reflects the full range of experience of a historical cohort. Because the data contain 43 years of actual covered earnings for each sample member as well as complete marital histories, the results give a comprehensive view of the outcomes that would have occurred for this cohort if it had experienced these alternative Social Security rules. ${ }^{12}$ Compared with other microsimulation models used to study the distributional effects of Social Security, this historical cohort model relies little on projected or imputed data.

${ }^{11}$ Social Security benefits are partially taxable for some upper-income taxpayers. I interpret this feature as part of the personal income tax system rather than the Social Security system and do not study it here.

${ }^{12}$ The model ignores behavioral responses to these alternative Social Security rules. 
Since I am particularly concerned about the lower tail of the benefit distribution, my ability to observe extreme cases and to reflect the complicated cross correlations between marital status, earnings, retirement, and mortality is important. ${ }^{13}$

Nonetheless, the simulation model requires two types of imputations. First, I construct earning histories for spouses who were absent at the time of the 1990/1991 SIPP (due to death or divorce). Second, I impute earnings for people located at the taxable maximum for years in which the taxable maximum was at a lower level relative to average wages than it is currently. Further details of the matching and imputation methods are described in the data appendix.

Once complete earnings and marital histories have been constructed, it is possible to calculate Social Security benefit streams for each individual at ages 60 through 100. I assume that sample members claim benefits at their actual retirement age (obtained from the Social Security benefit records), and then calculate Social Security benefits at each age from 60 to $100 .{ }^{14}$ For married and divorced sample members, the model calculates separate benefit streams corresponding to the benefits the sample member would receive if his or her spouse were still alive and the benefits if the spouse were dead (assuming that the sample member were still alive). Expected lifetime benefits can then be calculated by weighting each potential benefit-year by the probability that the sample member is alive in that year. For married and divorced individuals, the weights on each of the two benefit streams account additionally for the probability that the

${ }^{13}$ The drawback of analyzing an historical cohort is that future cohorts will differ along key dimensions from the 1925-1929 cohort. In particular, women will have much greater earnings and a larger share of individuals in later cohorts will be divorced or never married.

${ }^{14}$ Benefits vary by age because they can depend on whether the sample member's spouse has started receiving benefits and on whether the spouse is still alive. 
spouse is alive. To account for socioeconomic differences in mortality, I use separate mortality tables for each race-by-sex-by-education group that were constructed using a non-linear least squares regresssion to fit a standard actuarial function, the Gompertz-Makeham formula, to nonparametric age-specific mortality rates from the National Longitudinal Mortality Study. ${ }^{15}$

\section{Methodology for Measuring Redistribution}

This paper focuses on the redistribution in the retirement portion of Social Security. Contributions and benefits related to disability and pre-retirement survivors are not studied. ${ }^{16}$ Including these benefits would increase the measured amount of redistribution to lower socioeconomic groups. However, many Social Security reform plans would preserve disability benefits at current-law levels. ${ }^{17}$ Therefore, it is the redistribution in the retirement portion of Social Security that would most likely be affected by Social Security reform.

${ }^{15}$ These mortality estimates were developed in joint work with Jeffrey Brown and Joshua Pollet (see Brown, Liebman, and Pollet, 2002), and are the same as those used in Brown (2002) and Feldstein and Liebman (2002). We thank Hugh Richards for providing us with tabulations from the NLMS. We produced separate mortality tables by Hispanic status as well. However, because the data were much thinner and because the demography literature suggests that there is considerable heterogeneity in life expectancies across Hispanic groups, I decided not to differentiate by ethnicity in this paper. For evidence on Hispanic mortality, see Sorlie et al (1993) and Hummer et al (1999).

${ }^{16}$ Individuals receiving disability benefits according to the data from the Social Security Master Beneficiary Record are excluded from the sample. Thus, OASI benefits paid to formerly disabled beneficiaries after the age- 65 conversion of disability benefits to retirement benefits are not modelled.

${ }^{17}$ Elmendorf, Liebman, and Wilcox (2001) report that the individual-account based Social Security reform plans studied by the Clinton administration would have shielded DI benefits from cuts and one of President Bush's principles for Social Security reform is that "modernization must preserve Social Security's disability and survivors components." The NCRP plan is a notable exception that applied benefit cuts to disability benefits. 
In a social insurance program such as Social Security, the insurance and redistribution functions are closely related. Viewed from a point of time before an individual knows his socioeconomic status and therefore the distribution from which his lifetime earnings, marriage, and mortality experience will be drawn, all of the features of Social Security that result in some workers receiving higher returns on their contributions than others can be interpreted as insurance - insurance against living too long, having low-wages, and marrying a non-working spouse. From behind this veil of ignorance, all workers have the same ex ante expected return from Social Security and different outcomes that occur ex post are simply the payoffs from the social insurance; there is no redistribution. Alternatively, one could view the program from the standpoint of a worker who has just entered the workforce for the first time, say at age 25 . Based on education level, sex, and family background, this worker has an expected distribution of future earnings, marriage, and mortality experience. One could interpret differences in expected net benefits from Social Security across groups defined by characteristics pre-determined by age 25, such as race, education, and sex, as redistribution, and within-group variation as ex-post payoffs from the insurance. ${ }^{18}$

In this paper, I take a third approach and interpret Social Security as providing insurance solely against longevity risk, and attribute other differences in payoffs from Social Security to redistribution. In particular, differences in payoffs to Social Security due to different lifetime earnings and marriage patterns are considered to be redistribution. Differences due to expected mortality (from age 21 on), defined within sex-by-race-by-education groups are also interpreted

${ }^{18}$ Some of the results in Feldstein and Liebman (2002) can be interpreted in this way. A complete accounting of the benefits expected from Social Security at age 25 would also incorporate the disability and young survivors benefits that are omitted from my analysis. 
as redistribution. ${ }^{19}$ Differences in payoffs due to differences in the ex post mortality experienced by individuals within the sex-by-race-by-education groups are not considered redistribution and are integrated out by averaging over the possible dates of death with appropriate probability weights.

To implement this concept, I use three measures of redistribution. The first is the internal rate of return, $\boldsymbol{r}$, that equalizes the present discounted value of Social Security contributions and benefits:

$$
0=\sum_{\text {age }=21}^{\text {age }=100} \frac{S_{\text {age }}\left(B_{\text {age }}-T_{\text {age }}\right)}{(1+r)^{\text {age-21 }}},
$$

where $B$ represents Social Security Benefits, $T$ represents Social Security taxes, and $S$ represents the probability of living to a given age.

The second is the net transfer received from Social Security, a dollar measure of the difference between an individual's lifetime benefits and lifetime taxes:

$$
\text { NetTransfer }=\sum_{\text {age }=21}^{\text {age } 100} \frac{S_{\text {age }}\left(B_{\text {age }}-T_{\text {age }}\right)}{\left(1+r_{d}\right)^{\text {age- } 65}},
$$

Specifically, the net transfer is the present discounted value of the individual's lifetime Social Security benefits minus the present value of the individual's a lifetime taxes, discounted at a rate,

${ }^{19}$ This portion of the redistribution through Social Security is common to any system that requires everyone to annuitize at a single price. Brown (2002) discusses the redistribution that would occur in an individual account-based system that required everyone to annuitize at a single price. 
$r_{d}$, and measured as of age 65 . In order to focus on within cohort redistribution, the main results in this paper discount at the cohort rate of return, which for this cohort under the assumptions described below turns out to be 1.29 percent. Therefore, an individual who receives exactly the cohort rate of return on their Social Security taxes will have a net transfer of zero, while someone with a rate of return higher than that of the cohort will receive a positive transfer and someone with a lower rate of return will receive a negative transfer. I also show results for real discount rates of 3 percent and 5 percent.

The third measure of redistribution is the lifetime net tax rate from Social Security. This is simply the net transfer divided by the present discounted value of lifetime earnings.

Three details about the contribution and benefit streams affect the results. First, because only individuals who survive to the age at which they are interviewed in the SIPP are in the sample, I scale up the Social Security contributions of sample members to reflect the probability that a person in their sex-by-race-by-education group would not live to each age. Therefore, group averages on rates of return or transfers can be interpreted as the expected return for all individuals in that group who were alive as of age 21 .

Second, in order for my results to reflect the U.S. Social Security system in a steady state rather than one in which the rates of return earned by different cohorts are changing, and to make the results comparable to studies that focus on Social Security reforms that would be implemented over the coming century, I calibrate the life expectancies and payroll tax rates to reflect conditions in 2075, the endpoint of the Social Security actuaries' 75 -year horizon. In particular, I scale my estimated race-by-sex-by-education mortality tables to be consistent with the Social Security Administration's projections for individuals born in 1990, and I assume a 
payroll tax rate of 15.4 percent which is roughly the payroll tax rate that would be necessary to support the portion of OASI benefits modeled in this paper. ${ }^{20}$ Under these assumptions, the overall internal rate of return from Social Security for my simulation cohort is 1.29 percent. ${ }^{21}$

Third, because my unit of observation is the individual, I must allocate the payroll taxes and Social Security benefits of married couples across the two spouses. In years during which a married couple is married, I split the total payroll tax paid by the two spouses equally. Similarly, during retirement years in which both spouses are alive, the total Social Security benefits received by the couple are split equally into the benefit streams of each spouse. However, during years before the couple was married, the entire contribution of each spouse stays in the contribution stream of the spouse making the contribution, and Social Security benefits received after one spouse is dead are credited only to the surviving spouse. This approach implies that (except for differential earnings before marriage) the entire difference in rates of return and transfers between two spouses comes from the longer life expectancy of the wife. ${ }^{22}$

${ }^{20}$ Of the total 19.9 percent of payroll in OASDI costs that are forecast for 2075 (Board of Trustees, 1999), 2.59 percent are for DI benefits, roughly 0.28 percent are for young survivors (including children), and roughly 1.6 percent are OASI benefits at ages 65 and above for people who converted from DI benefits when they reached the full-benefit age. The DI estimate comes directly from Board of Trustees (1999). The other two estimates rely on Table II.H2 in the 1999 Trustees' Report which provides estimates of the number of beneficiaries of each type in future years and weights these estimates by the average benefit levels for each type of beneficiary in 1997 from the Annual Statistical Supplement to the Social Security Bulletin.

${ }^{21}$ This is similar to the long run growth rate of the tax base of 1.1 percent that is assumed by the Actuaries. One reason my estimate is larger is that my sample contains many more oneearner couples than the population retiring in 2075 will likely contain.

22 The approach I take in this paper is appealing because it shows women receiving a higher rate of return from Social Security than men, as their longer life expectancy would imply. Two other plausible approaches are less satisfactory. One would be to credit each spouse with only his or her own tax contributions and Social Security benefit. This would result in much 
Several other methodological issues deserve attention. In examining the relationship between redistribution from Social Security and lifetime income, the particular definition of income used to classify individuals can have a large impact on the results. I use two different lifetime income measures based on earnings histories. The first is the average indexed monthly earnings (AIME) of the higher earner in the household. The AIME is the measure of income used by the Social Security benefit formula and is calculated by summing the highest 35 years of earnings (wage indexed and including zeros if any) for the worker and dividing by 420 (35 x 12). I use only the higher earner's AIME for two reasons. First, the AIME of the higher earner is likely to be a good measure of a household's socioeconomic class and will not be confounded by the large variation in the earnings levels of secondary earners. Indeed, since most higher earners work full-time for at least 35 years, this measure is similar to the potential earnings measures used in the studies by Coronado, Fullerton, and Glass (2000) and Gustman and Steinmeier (2000b). Second, for most couples, the Social Security benefit they receive depends only on the AIME of the highest earner, providing no marginal benefit for work by the lower-earning spouse. ${ }^{23}$ Thus, the AIME is the income measure around which the explicit redistribution in the Social Security system is based.

higher measured rates of return for women (infinite in the case of non-working spouses) and low rates of return for men because it would give them no credit for the spouse benefits produced by their earnings history. This would be unsatisfactory because the men in married couples are clearly benefitting from their spouses receiving enhanced benefits. Another approach would be to credit men with the entire benefit produced by their earnings histories including the spouse benefit. This approach is unsatisfactory because it would calculate the rates of return for many wives as zero even though they are getting a "very good deal" from Social Security.

${ }^{23}$ The Social Security Administration reports that 63 percent of women beneficiaries currently receive no marginal benefit from their own earnings and that this percentage is expected to fall to 40 percent in 2060. (National Economic Council, 1998) 
The second measure I use is the total covered earnings of both members of the couple (accumulated to age 65 at the relevant discount rate). The appeal of this second measure is that it allows for comparison with the many studies that analyze the impact of government programs on the income distribution using actual rather than potential income data, and it also corresponds to the Social Security tax base. This second measure of income may not however be satisfactory for welfare analysis, because a non-trivial portion of the variation in this measure is due to the laborleisure (or market production versus home production) choice of the secondary earner and not simply to the earnings potential of the household.

It is also worth emphasizing that in some cases, the financial calculations presented in this paper may not provide sufficient information to draw comparisons about the welfare impacts of Social Security on different groups. In particular, income redistribution is only one of the benefits provided by Social Security, and some of the other benefits - such as the inflation protected annuity and absence of market risk - may be particularly valuable to low-income families. Moreover, the lifetime perspective on redistribution taken in this paper may not be the proper one if people who live to older ages are seen as having greater total resource needs than people with shorter lifespans as opposed to as having received a valuable benefit - in the form of a longer life - that was not received by the shorter lived.

\section{Redistribution in the Current System}

A. Overall Redistribution

The theoretical progressivity of the Social Security system can be seen in figure 1 which abstracts from all of the non-income sources of redistribution by graphing the relationship 
between AIME and net transfers from Social Security for a hypothetical set of single adults with different earnings levels but the identical timing of earnings throughout their lifetime and identical life expectancies. For comparison with the results to come, the transfers are calculated discounting at the 1.29 percent rate that matches the aggregate internal rate of return on Social Security for the microsimulation sample and the mortality table used is the average of those for white males and white females. Initially, transfers rise with income as the Social Security benefit formula replaces 90 percent of the first $\$ 505$ dollars of monthly earnings, reaching a maximum net present value of roughly $\$ 38,000$ at an annualized AIME of $\$ 6,060 .{ }^{24}$ Then they fall with income, first at a relatively gradual rate during the range over which the benefit formula replaces 32 percent of earnings, and then at a more rapid rate after the second bend point. Transfers are mostly negative in this figure because the single adults are not benefitting from spouse benefits. For an individual with an annualized AIME of $\$ 50,000$, the net transfer is - $\$ 150,000$.

Figure 2 shows the actual distribution of net transfers from Social Security with a discount rate of 1.29. In contrast to the striking theoretical relationship between income and net transfers from Social Security in the previous figure, figure 2 reveals that transfers can differ widely at a given level of household head AIME. Moreover a substantial number of high income individuals receive greater transfers than the typical low-income individual does. For example, 19 percent of individuals in the top AIME quintile receive transfers than are greater than the average transfer for people in the lowest AIME quintile, and 23 percent of top quintile individuals receive transfers that are greater than the average transfer received by people in the

\footnotetext{
${ }^{24}$ The portion in which transfers rise with income can be thought of as similar to the phase-in region of the earned income tax credit in that it limits the amount of transfers to people with very small earnings who are likely to be unusual cases rather than full-time working poor.
} 
second lowest quintile.

Some of the variation in transfers at a given level of AIME can be attributed to the difference between the transfers received by men and women in the same household - the wives receive larger transfers due to their longer life-expectancies. This source of variation is highlighted in figure 3 which separates the male and female observations from figure 2 into separate plots. However, substantial variation remains in transfers at a given AIME even looking only at males. This variation is due to differences in life expectancies, marital status, the level of earnings of secondary earners, the share of earnings earned in years outside of the highest 35 years, and the timing of earnings over the lifetime.

Despite the wide spread of transfers at a given level of annualized AIME, it is important to emphasize that the kernel regression line in figure 2 showing mean transfers at a given level of income declines steadily with income (though the decline is not nearly as steep as the theoretical decline shown in figure 1). The regression line reaches at maximum of around $\$ 33,000$ at an annualized AIME of $\$ 8000$ and falls to roughly $-\$ 25,000$ at $\$ 50,000$ of annualized AIME.

Figure 4 shows the distribution of internal rates of return from Social Security for the same sample. The average internal rate of return falls from around 4 percent down to around 1 percent as incomes rise. As with the transfer plots, there is wide variation in internal rates of return at a given level of AIME.

As discussed above, different definitions of income can lead to different interpretations of the strength of the relationship between income and the transfers from Social Security. In Figure 2 , many of the individuals receiving very low transfers are people in married couples in which the secondary earner has substantial earnings. If the earnings of these secondary earners were 
included in the definition used for ranking household income, then these low transfer families would be considered to have higher incomes and the transfers would appear more progressive overall. Figure 5 shows transfers graphed against the total average annual earnings of both spouses. In addition to including the earnings of both spouses, this measure also includes all years of earnings, not just the highest 35 . The spread of transfers at a given level of earnings is now much tighter, largely because people with low returns due to having a large amount of earnings that produce little or no marginal Social Security benefits are now classified as having higher earnings. But the extent that variations in earnings from secondary earners reflects a choice between home and market production rather than a difference in earning capacity, this total earnings measure of income may be a less satisfactory metric for ranking people than the measure based on the AIME of the primary earner.

The difference between the two measures of income can be seen in the first part of Table 2 which presents internal rates of return, mean transfers, and lifetime net tax rates by income quintile under the two definitions of income. The first column presents the average annual earnings by quintile. The numbers for all beneficiaries and for the AIME quintiles are the AIME of the highest earner in the household, and therefore correspond to the results in figures 2 through 4. The last five rows use the total earnings measure as in figure 5. Note that the average income under the more comprehensive measure can be lower than that in the less comprehensive measure because the averaging is over more years. The second column presents the average internal rate of return from Social Security by income quintile. These average rates of return are person weighted, not dollar weighted, and therefore the average internal rate of return for all beneficiaries (1.53 percent) exceeds the aggregate cohort rate of return (1.29 percent) mentioned 
above. Rates of return range from 2.70 to 0.85 for the AIME measure of income, and from 3.06 to the 0.35 for the total earnings measure. Thus low-income individuals clearly receive a higher rate of return from Social Security than higher-income individuals and the difference between the rates of return of high-income and low-income individuals is greater when the individuals are ranked by total earnings than when they are ranked by the AIME of the primary earner.

The remaining six columns in the first part of table 2 show the net transfer from Social Security evaluated at age 65 and the lifetime net tax rate from Social Security. Results for each of these two measures are presented using discount rates of 1.29 percent (the cohort internal rate of return), 3 percent, and 5 percent. The lifetime net tax rate is calculated by dividing the net transfer from Social Security by the present value of lifetime covered earnings. ${ }^{25}$

At a discount rate of 1.29 percent, individuals in the lowest AIME quintile receive $\$ 26,375$ more in Social Security benefits than they pay in taxes and those in the second quintile receive a net transfer of $\$ 17,932$. In contrast, individuals in the highest AIME quintile pay $\$ 33,571$ more in taxes than they receive in benefits. Those in the lowest quintile receive a net subsidy from Social Security equal to 6 percent of lifetime earnings and those in the second quintile receive a net subsidy of 1.7 percent, while those in the highest quintile face a net tax from Social Security equal to 2 percent of lifetime earnings.

It is worth noting that the composition of the lowest AIME quintile is quite different from that of the other quintiles. 56 percent of primary earners in the first quintile had fewer than 35

${ }^{25}$ Because the denominator in this calculation is covered earnings, the lifetime net tax rates rise monotonically by income group. A measure of lifetime net tax rates which included earnings above the maximum level on which Social Security taxes are assessed would start to decline at income levels above the taxable maximum. 
years of work in covered employment, compared with 22 percent in the second quintile, 13 percent in the third quintile, and less than 2 percent in the fourth and fifth quintiles. 20 percent of people in the first quintile are immigrants, compared with 5 percent in the other four quintiles. As Gustman and Steinmeier (2000a) have shown, immigrants receive a very good deal from Social Security because they are credited with zeros in their earnings records for the years before they came to the U.S., thereby appearing to have low lifetime earnings and benefitting from Social Security's progressive benefit formula. Many of the non-immigrants in this first quintile are likely to have worked in non-covered sectors of the economy and therefore their years with zero earnings are not true zeros. ${ }^{26}$ Thus, an argument could be made for ignoring the results for the lowest income quintile and focusing on the remaining four quintiles.

At higher discount rates, all income quintiles have negative transfers from Social Security on average and the spread between the average transfers at different income levels grows. For example, at a discount rate of 1.29 , there is a $\$ 51,000$ difference in net transfers between the second and fifth AIME quintiles; at a discount rate of 3 percent this difference reaches $\$ 109,000$; and at a discount rate of 5 percent it reaches $\$ 218,000$. With the higher discount rates, lifetime net tax rates are positive at all income levels, but the variation in lifetime tax rates by income levels falls since with a higher discount rates the progressive benefits (which occur later than the taxes) are reduced in importance relative to the proportional Social Security tax.

The second part of table 2 presents the analogous results broken down by sex, race, and

${ }^{26}$ I excluded government workers (who in the past were not covered by Social Security) from my sample by dropping observations for individuals who could be identified in the SIPP work history topical module as having worked in the public sector or who were receiving income from a government pension. However, this procedure presumably did not identify all workers with public sector experience. 
level of education. As would be expected due to their lower mortality rates, women receive substantially larger transfers and rates of return than men. Discounted at the cohort rate of return of 1.29 percent, the average transfer for women is $\$ 37,047$, while the average for men is $-\$ 43,108$. Women receive a rate of return on the Social Security contributions of their household of 2.18 percent, compared with 0.78 percent for men.

Surprisingly, differences in transfers across race and education groups are generally not statistically significant, and differences in rates of return for these categories are of borderline significance. For example blacks receive an internal rate of return of 1.64 percent compared to 1.52 percent for whites. The first column shows that AIMEs do differ substantially by race and education. But the progressive benefit formula is completely offset by the higher mortality in the lower-income groups. This can be seen clearly in table 3 which reproduces selected internal rate of return and net transfer results from table 2 and then adds results using mortality tables that vary only by sex (and not by race or education). ${ }^{27}$ Whereas rates of return in different race and education groups are indistinguishable once differential mortality is accounted for, with uniform mortality rates low-income groups such as blacks and people with less than high school education have higher internal rates of return and transfers than the groups with higher average earnings.

In both sets of columns, Hispanics have returns and transfers that are significantly above whites and blacks. In this cohort, a large share of the Hispanics are immigrants, and as mentioned above, the progressive benefit formula strongly advantages immigrants with short

27 Specifically, all men are assigned the white male mortality table and all women are assigned the white female mortality table. 
periods of covered employment. In fact, the transfers for Hispanic immigrants are likely to be understated in these results. While precise lifetables for U.S. Hispanics are difficult to construct, the available evidence suggests that U.S. Hispanics (particularly Hispanic immigrants) have mortality rates that are lower than those for non-Hispanic whites, and my results do not take into account these lower mortality rates. ${ }^{28}$

\section{B. Factors Offsetting Income-related Redistribution}

Table 4 contains results analyzing the extent to which spouse and survivor benefits and differential mortality reduce the amount of income-related redistribution accomplished by Social Security. The first column of the table contains the present value of Social Security taxes for each income quintile. ${ }^{29}$ The second column contains the present value of Social Security benefits under two counterfactual assumptions. First, it calculates Social Security benefits with individuals receiving only their retired worker benefit and not spouse or survivor benefits.

Second, it assumes that mortality rates vary only by sex and age and not by race and education. Thus this column describes what the distribution of Social Security benefits would be if differential mortality and spouse and survivor benefits did not exist.

The next two columns remove each of these two counterfactual assumptions one at a time. Column three shows benefit levels with spouses and survivor benefits added in, but

${ }^{28}$ For evidence on Hispanic mortality, see Sorlie et al (1993) and Hummer et al (1999).

${ }^{29}$ These are the same values for Social Security taxes that underlie the basic results in tables 1 and 2. Mortality assumptions affect Social Security tax payments because my model incorporates the impact of mortality before age 65 . However, because the impact of different mortality assumptions on the present value of Social Security taxes paid by different income quintiles is extremely small, I ignore this effect in this table. 
retaining the counterfactual assumption that mortality rates vary only by sex and age. Thus the difference between column three and column two shows the impact of spouse and survivor benefits. Because spouse benefits are 50 percent of the benefit of the retired worker to whom the spouse is married and survivor benefits are 100 percent of the benefit of the deceased retired worker, the size of these benefits is higher for those in the higher AIME quintiles. On average, individuals in the lowest AIME quintile gain $\$ 27,776$ from the introduction of spouse and survivor benefits, individuals in the middle quintile gain $\$ 46,889$, and individuals in the highest AIME quintile gain $\$ 52,158$. Thus one could argue that the Social Security system implicitly values the time out of the labor force of women married to high earning men more than that of women married to lower earners.

Viewed as a percentage increase, however, spouse and survivor benefits simply lead to a equal percentage increase in benefits across most of the quintiles with a somewhat higher percentage increase in the benefits of the lowest earning group. The bottom panel of the table shows benefit levels for each earnings quintile scaled so that the benefits for each group in column 2 equal 100. Introducing spouse and survivor benefits increases benefit levels by about 30 percent in the four highest quintiles and by about 40 percent in the lowest quintile. Thus, in evaluating the distributional implications of spouse and survivors benefits one needs to have in mind a specific alternative for what would occur with the extra revenue if it were not used for these benefits. If the alternative were a proportional increase in all benefits or a reduction in the payroll tax, spouse benefits have little impact on the amount of redistribution that occurs through Social Security. If the alternative is to raise the benefits or reduce the taxes of each beneficiary by an equal dollar amount, then spouse and survivor benefits cause substantial redistribution 
toward high income households.

Differential mortality has a smaller impact on benefits levels, causing average lifetime benefits to fall in the lowest AIME quintile by about $\$ 3,330$ or about 2 percent. In contrast, benefits rise in the highest AIME quintile by $\$ 2,424$ or about 1 percent. These effects are somewhat smaller than the effects on education and race groups shown in table 3 because the income groups contain a mixture of the various race and education groups. Recent research by Deaton and Paxson (2001) suggests that income has a direct impact on mortality independent of race and education. Incorporating this direct effect of income would increase the effect of differential mortality on the benefit levels of the different income quintiles.

\section{How Much Income-Related Redistribution is There?}

The scatter plots and means make it clear that there is both a substantial amount of income-related redistribution occurring through Social Security, and a substantial amount of redistribution that is not income related. However, the results presented so far do not provide a clear measure of what the total magnitude of the redistribution is. While no summary measure of redistribution is perfect, a sense of the total magnitude is useful for understanding how important the income redistribution is from Social Security relative to other U.S. income-transfer programs and for thinking about how large an income-based transfer system would be needed to supplement an individual account-type Social Security system in order to preserve the current level of income-based redistribution.

The first row of Table 5 shows that the present value of total Social Security benefits per 
birth year in my simulations is $\$ 460$ billion. ${ }^{30}$ Adding up the total transfers received by individuals receiving more than the cohort rate of return (which is also equal to the negative transfers of those receiving less than the cohort rate of return) results in total transfers of $\$ 60$ billion, roughly 13 percent of total benefits. To measure the portion of these transfers that are income related, I replace each individual's transfer with the predicted transfer for a person of that income estimated by the kernel regression lines through the scatter plots in Figures 2 and $5 .{ }^{31}$ Adding up the income related transfers calculated in this way, produces an estimate of $\$ 23$ billion in income-related transfers under the AIME measure of income and $\$ 42$ billion under the total-income measure of redistribution, suggesting that between 38 and 70 percent of Social Security transfers and between 5 and 9 percent of Social Security benefits go for income-related transfers. OASI benefit payments in 2001 are projected to be $\$ 373$ billion dollars. 5 to 9 percent would therefore be between $\$ 19$ and $\$ 34$ billion dollars of annual income-related transfers.

This measure of income-related transfers is quite sensitive to the discount rate used. At a discount rate of 3 percent, income-related transfers are between 17 and 23 percent of benefits and at a discount rate of 5 percent they are between 42 and 54 percent. ${ }^{32}$ This result is closely related

${ }^{30}$ This is an average over the five birth years, in 1999 dollars, discounting at the cohort rate of return of 1.29 percent.

${ }^{31}$ An equivalent way to describe this measure of income-related transfers is that it is the total of all the transfers from individuals at income levels above the point where the average transfer becomes negative to people at income levels below that point.

${ }^{32}$ For discount rates above 1.29 percent, aggregate transfers are negative rather than zero. For these calculations, transfers for each individual are measured relative to the average dollar transfer for the cohort. 
to the point made earlier about the important interactions between intercohort and intracohort redistribution. When the interest rate used to discount Social Security benefits and taxes is lower than the cohort rate of return (as was the case for some early generations of beneficiaries), dollar measures of intracohort redistribution look regressive since a large share of the windfalls go to upper-income beneficiaries with high benefit levels. In contrast when the discount rate is above the cohort rate of return, dollar measures of the progressivity of the system show the high-income individuals who pay larger amounts of taxes losing the most from the low return on these tax payments.

In interpreting these results it is important to remember that the income-transfers from Social Security differ in a number of important ways from transfers in other programs. First, because Social Security transfers vary so much at each income level, crediting Social Security for accomplishing the mean transfer at each income level exaggerates its effectiveness relative to other income-transfer programs that give everyone at a given income level the intended transfer. ${ }^{33}$ That said, there are also advantages of transfers through Social Security. Lifetime income is almost surely a better measure of a person's true ability than income in a single year, and it is possible that redistribution that occurs after retirement results in less distortion of labor supply than redistribution that occurs during working years. Moreover, some of the redistribution that occurs for non-income related reasons like rewarding people with long life expectancies could be desirable if the goal is to ensure a constant replacement rate throughout retirement.

${ }^{33}$ I.e. the added variance from the Social Security transfers reduces utility relative to a transfer that provided everyone at the income level with the mean transfer for that income level. 


\section{Discussion}

Three other papers have recently provided evidence on the amount of redistribution occurring through Social Security. ${ }^{34}$ Although the papers use different microsimulation models and often present different measures of redistribution, the results, when comparable, are quite similar to the ones in this paper and together suggest a consistent picture of Social Security's distributional effects. Caldwell et al (1998) use a microsimulation model based on projections of marriage and earnings patterns for postwar generations. The net tax rates that they calculate for the 1990 birth cohort (the cohort whose mortality patterns my results are calibrated to) range from 6.2 percent in the first income decile to 8.9 percent in the sixth income decile (and then fall in the upper deciles since their measure of income is not capped at the Social Security taxable maximum). ${ }^{35}$ These net tax rates are somewhat lower than mine because Caldwell et al assume a 14.6 percent OASI payroll tax in the long run, while I assume a 15.4 percent tax rate. Gustman and Steinmeier (2000b) use a microsimulation model based on the Health and Retirement Survey linked to Social Security earnings histories. They emphasize that Social Security looks less progressive after grouping individuals into families and adjusting for variation in secondary earner levels than it does looking simply at retired worker benefits. Using a family measure of lifetime income that averages only those years with significant earnings, they find that the redistribution from Social Security increases benefits in the second decile by 7 percent and reduces them by 7 percent in the ninth decile. Coronado, Fullerton, and Glass (2000) project

\footnotetext{
${ }^{34}$ The main work on all three of these projects occurred contemporaneously with my work and the various authors were not aware of each other's projects until the papers were first presented.

${ }^{35}$ These results come from discounting at a 5 percent rate of return.
} 
future earnings and marriage patterns for a PSID- based sample. Ranking households by potential earnings and taking into account the fact that wages above the taxable maximum are not taxed, they conclude that at a sufficiently high discount rate, Social Security is slightly regressive.

There are two closely-related implications of my findings for Social Security reform. First, the results suggest the magnitude of redistribution that an individual-account based plan would need to achieve in order to maintain the current level of redistribution from high-income families to low-income families. If distributionally-neutral individual accounts completely replaced Social Security, the equivalent of $\$ 20$ to $\$ 30$ billion per year of redistribution from people with high lifetime earnings to people with low lifetime earnings would be required to maintain current levels of redistribution. In a distributionally-neutral mixed plan in which individual accounts were responsible for only around one-third of the retirement income from Social Security, the equivalent of $\$ 7$ to $\$ 10$ billion per year in transfers would be required. However, because most individual-account plans would mandate at least partial annuitization, such plans would not be distributionally neutral and would result in the same redistribution from short-lived groups to long-lived groups that occurs in the current system. This implies that several billion additional dollars of transfers would be needed in an individual-account plan for it to match the redistribution of the current system. There are many ways such transfers could be implemented. For example, contributions to individual accounts could be made in a redistributive way; payouts from the accounts of high earners could be taxed to subsidize payouts from the accounts of low earners; annuity prices could be permitted to vary by income decile; or general revenues could be used to provide supplemental payments to lower earners. 
The second implication of these results for Social Security reform is that if no explicit steps are taken in an individual-account based plan to redistribute to groups with low life expectancies, then these groups could end up doing substantially worse than they do under the current system. In particular, blacks and high school drop outs currently receive rates of return from Social Security that are roughly the same as the population average, because the progressive benefit formula offsets the impact of their relatively high mortality rates. If an individualaccount based plan required annuitization at a single price for everyone in the population, then the same effect of mortality on benefit payments would occur as in the current system, but there would not be the progressive benefit formula to offset it. Providing explicit redistribution as part of the individual accounts would be one way to ensure that these groups are not made worse off by Social Security reform. Other ways of offsetting the mortality effects include providing for bequests and coming up with sufficient additional resources in funding the account so that retirement income levels are preserved (see Feldstein and Liebman, 2002).

In addition, these findings raise the question of how the Social Security benefit formula might be modified to align its distributional impact more closely with the theoretical impact shown in figure 1. There are two aspects of this: changing the average level of redistribution at different income levels and reducing the spread of transfers at a given income level. It would be relatively straightforward to increase transfers at low income levels and reduce them at higher income levels. The 90 percent factor in the PIA formula could be increased and the 32 and 15 percent factors could be reduced. Or if the goal was to concentrate the benefit increase on lowearners, but not the atypical low earners in the first quintile, the range over which the 90 percent benefit factor applies could be extended or a fourth range between 90 and 32 could be 
introduced.

Reducing the variation in transfers at a given level of income is more difficult and in some cases may not be desirable. Any retirement system that requires people to annuitize at a single rate will redistribute from those with short life expectancy to those with long life expectancy. One view of this sort of redistribution is that the correlation between income and life expectancy leads to perverse transfers from lower lifetime-income groups to higher lifetimeincome groups. But it is also possible to view people with longer life expectancies as having greater resource needs in which case some redistribution to them could be optimal. Although it is unlikely that the political system would ever explicitly provide higher benefit levels for groups with lower life expectancy, adding bequest options similar to the 10 -year certain options in private annuity plans would increase transfers to demographic groups with high mortality rates. Reducing transfers between households with working and non-working spouses could be accomplished by reducing spouse benefits (for example by capping them at 50 percent of the PIA of the average earner) and raising worker benefits. Alternatively, secondary earners could receive a federal income tax credit for their payroll taxes at the end of the year. Since female earnings levels have increased in more recent cohorts the importance of spouse benefits will decrease over time, and by some measures the progressivity of Social Security will increase.

\section{Conclusion}

Social Security provides income-related transfers that are between 5 percent and 9 percent of Social Security benefits paid, or $\$ 19$ to $\$ 34$ billion, at 2001 aggregate benefit levels (discounting at the 1.29 percent rate of return on Social Security earned by the microsimulation 
sample in this study). However, the range of transfers received at a given level of average lifetime income is quite wide. The wide variation in transfers at a given level of income is due to different mortality rates for people in different demographic groups, to variation in earnings levels by secondary earners, and to marital status differences, among other factors.

These results indicate that the income-based redistribution in the current Social Security system is fairly modest compared to the total benefits paid. But it is worth emphasizing that income redistribution is only one of the benefits provided by Social Security, and some of the other benefits - such as the inflation protected annuity and absence of market risk - may be particularly valuable to low income families. Therefore, when comparing alternative systems to the current Social Security system, it will be important to examine not only whether they can raise the incomes and lower the poverty rates of low income families, but also whether they can provide a comparable amount of income security. ${ }^{36}$

${ }^{36}$ Feldstein and Liebman (2002) show that a mixed-plan that adds three percent individual accounts on top of a pay-as-you-go system that continues to be funded with 12.4 percent of payroll can, in the long run, substantially reduce the percentage of Social Security recipients with benefits below the poverty line. 


\section{Data Appendix}

The data set is created by matching the 1990 and 1991 panels of the Survey of Income and Program Participation(SIPP) to Social Security administrative records on earnings from 1951 through 1993 (the Summary Earnings Record -- SER) and benefit records from 1995 (the Master Beneficiary Record -- MBR) for those same individuals.

From the public use sample of the SIPP, I selected all individuals from the first wave of each SIPP panel who were age 60 or above in 1990 (individuals who were 60 years or above at the start of the 1990 panel, 61 years or above at the start of the 1991 panel). I also used variables on marital history from the wave-two topical module of the SIPP, and included data on spouses of people in the age range, even if they themselves were not in the age range. The ultimate unit of observation is the individual, so a married couple with two individuals in the appropriate age range would be counted as two observations. Observations that did not match to the SER were dropped from the sample, and the weights of the remaining observations were scaled up.

Next I created the sample cohort -- individuals who were born from 1925 through 1929. 1929 was chosen as a cut off because it ensures that earnings can be observed through age 64 for everyone in the sample. The goal was to have as narrow an age group as possible so that there would not be age groups that had already lost significant numbers of Social Security beneficiaries due to death. However, given the modest sample sizes, I decided to use 5 birth years of data. I dropped individuals whose year of birth in the SER was more than 5 years from their year of birth in the SIPP.

For the never married and married individuals, the SIPP-SER match produced the 
earnings data necessary for the simulation. ${ }^{1}$ For previously married individuals, however, the former spouse is not in the data set, so I did not have the spouse's SER earnings record. For many of these individuals (those receiving spouse benefits, widow/er benefits, or dually entitled worker benefits), I was able to obtain the former spouse's Primary Insurance Amount (and therefore their Average Index Monthly Earnings) by further matching to the MBR. For the rest (those receiving retired worker benefits only), I imputed a spouse PIA using the correlation between respondent and spouse PIA for similar individuals from the New Beneficiary Survey -an older sample that obtained earnings and benefit records for former spouses of sample members. I dropped disabled individuals (and couples with a disabled member) and unstacked married couples so that each individual in the couple counts as an observation if both spouses were members of the 1925 to 1929 birth cohort.

Once I had a former spouse's PIA for the previously married individuals, I calculated an Average Indexed Monthly Earnings (AIME) by inverting the Social Security benefit formula. I then calculated (separately for men and women) the average share of earnings earned in each year for people in our sample with earnings histories (separately for men and women), and generated an earnings record for the missing spouses by spreading their AIME according to the average share of earnings earned in each year, subject to the constraint that a former spouse of a widow or widower could not have earnings in years after his or her death.

The earnings data report earnings only up to the taxable maximum for the year. In the past, the taxable maximum was much lower relative to average earnings than it is today. In order

${ }^{1}$ In some cases, it was necessary to impute earnings at the beginning or end of the career if the 1951-1993 period did not include all years from age 21 to age 64 . 
to be able to simulate the current Social Security rules, I imputed a level of earnings above the taxable maximum for sample members with earnings at the taxable maximum. I did this by estimating a two-limit tobit regressed on a constant (i.e. with no other independent variables) separately for men and women for each year between 1951 and 1993. The level of earnings is fit very well by a normal distribution until a percentile that is above the current taxable maximum. The regressions produced an estimate for mean earnings and a regression error. Using these parameter estimates, I randomly drew from a normal distribution will the appropriate mean and variance until each topcoded observation was replaced with a draw above the topcode.

Based on the sample member's earnings history and the earnings history of the spouse, I calculated Social Security benefits. Our calculations incorporate nearly all of the retirement benefit provisions, including covered worker requirements, the minimum benefit, spouse benefits, survivor benefits, and reductions for claiming benefits before the normal retirement age. I do not simulate the delayed retirement credit (instead assuming that everyone in the sample claims benefits by age 65), nor do I have adequate information to implement government pension offset provisions. However, workers were dropped from the sample if they were receiving a government pension according to the SIPP or if they had evidence of government employment in the SIPP topical module on employment histories. 


\section{References}

Aaron, Henry (1977). "Demographic Effects On the Equity of Social Security Benefits," in Martin Feldstein and Robert Inman, editors. The Economics of Public Services (London: Macmillan Press), 151-173

Board of Trustees of the Federal Old-Age and Survivors and Disability Insurance Trust Funds (1999). The 1999 Annual Report of the Board of Trustees of the Federal Old-Age and Survivors Insurance and Disability Insurance Trust Funds. (Washington, DC: Social Security Administration).

Board of Trustees of the Federal Old-Age and Survivors and Disability Insurance Trust Funds (2001). The 2001 Annual Report of the Board of Trustees of the Federal Old-Age and Survivors Insurance and Disability Insurance Trust Funds (Washington, DC: Social Security Administration).

Boskin, Michael J., Laurence J. Kotlikoff, Douglas J. Puffert, and John B. Shoven (1987). “Social Security: A Financial Appraisal Across and Within Generations," National Tax Journal 40:3, 19-34.

Brown, Jeffrey (2002). "Differential Mortality and the Value of Individual Account Retirement Annuities," in Martin Feldstein and Jeffrey Liebman, editors, Distributional Aspects of Social Security and Social Security Reform (Chicago: University of Chicago Press).

Burkhauser, R. and J. Warlick (1981). "Disentangling the Annuity from the Redistributive Aspects of Social Security in the United States." The Review of Income and Wealth, $27: 4,401-21$.

Burtless, Gary (1994). "Public Spending on the Poor: Historical Trends and Economic Limits," 
in Sheldon Danziger, Gary Sandefur, and Daniel Weinberg, editors. Confronting Poverty: Prescriptions for Change (New York: Russell Sage Foundation), 51-84.

Caldwell, Steven, Melisssa Favreault, Alla Ganman, Jagadeesh Gokhale, Thomas Johnson, and Laurence J. Kotlikoff (1999). “Social Security’s Treatment of Postwar Americans.” Tax Policy and the Economy, 13, 109-48.

Coronado, Julia, Don Fullerton, and Thomas Glass (2000). "The Progressivity of Social Security.” NBER Working Paper 7520. February.

Deaton, Angus and Cristina Paxson (1999). "Mortality, Education, Income and Inequality Among American Cohorts." In David Wise, editor, Themes in the Economics of Aging (Chicago: University of Chicago Press), 129-170.

Duggan, James E., Robert Gillingham, and John S. Greenlees (1993). "Returns Paid to Early Social Security Cohorts," Contemporary Policy Issues, 11:4, 1-13.

Duggan, James E., Robert Gillingham, and John S. Greenlees (1995). Progressive Returns to Social Security? An Answer from Social Security Records. Unpublished paper U.S. Treasury Department.

Elmendorf, Douglas, Jeffrey Liebman, and David Wilcox (2001). "Fiscal Policy and Social Security Reform in the 1990s" forthcoming in Jeffrey Frankel and Peter Orszag editors, American Economic Policy in the 1990s (Cambridge: MIT Press).

Feldstein, Martin and Jeffrey Liebman (2002). “The Distributional Effects of an InvestmentBased Social Security System," in Martin Feldstein and Jeffrey Liebman, editors, Distributional Aspects of Social Security and Social Security Reform (Chicago: University of Chicago Press). 
Garrett, Daniel M. (1995). The Effects of Differential Mortality Rates on the Progressivity of Social Security, Economic Inquiry, 33:3, 457-75.

Gustman, Alan and Thomas Steinmeier (2000a). "Social Security Benefits of Immigrants and U.S. Born,"in George Borjas, editor, The Economics of Immigration (Chicago: University of Chicago Press), 309-350.

Gustman, Alan and Thomas Steinmeier (2000b). "How Effective is Redistribution Under the Social Security Benefit Formula?’NBER Working Paper 7597, March.

Hummer, Robert A., Richard G. Rogers, Charles B. Nam, and Felicia B LeClere (1999). Race/Ethnicity, Nativity, and U.S. Adult Mortality, Social Science Quarterly, 80:1, 136153.

Hurd, Michael D., and John B. Shoven (1985). “The Distributional Impact of Social Security,” in Pensions, Labor, and Individual Choice, edited by David A. Wise. (Chicago: University of Chicago Press) 193-207.

Kitagawa, E.M. and P.M. Hauser (1973). Differential Mortality in the United States: A Study in Socioeconomic Epidemiology. (Cambridge: Harvard University Press).

McClellan, Mark and Jonathan Skinner (1997). The Incidence of Medicare. NBER Working Paper 6013. April.

National Economic Council (1998). Women and Retirement Security. Interagency Working Group on Social Security. Available at http:/www.ssa.gov/policy/pubs/sswomen.pdf. Panis, Constantijn and Lee Lillard (1996). Socioeconomic Differentials in the Returns to Social Security. RAND Corporation Report: DRU/1327/NIA. February.

Pappas, Gregory, Susan Queen, Wilbur Hadden, and Gail Fisher (1993). “The Increasing 
Disparity in Mortality Between Socioeconomic Groups in the United States, 1960-1986.” New England Journal of Medicine, 329:2, 103-109.

Rogot, Eugene, Paul D. Sorlie, and Norman J. Johnson (1992). "Life Expectancy by Employment Status, Income, and Education in the National Longitudinal Mortality Study,” Public Health Reports, 107:4, 457-461.

Social Security Administration (2000). Fast Facts and Figures About Social Security. Office of Policy. Office of Research, Evaluation, and Statistics. Available at http://www.ssa.gov/statistics/fast_facts/2000/ff2000.pdf.

Sorlie, Paul D., Erick Backlund, Norman Johnson, and Eugene Rogot (1993). “Mortality by Hispanic Status in the United States," Journal of the American Medical Association, 270:20, 2464-2468.

Steuerle, C. Eugene and Jon M. Bakija (1994). Retooling Social Security for the $21^{\text {st }}$ Century. (Washington, DC: Urban Institute Press). 
Table 1: Annual Redistribution from the U.S. Social Security System for 1998

\begin{tabular}{|c|c|c|c|c|}
\hline & $\begin{array}{l}\text { OASDI benefits } \\
\text { (billions of } \\
\text { dollars) }\end{array}$ & $\begin{array}{l}\text { OASDI payroll } \\
\text { taxes (billions of } \\
\text { dollars) }\end{array}$ & $\begin{array}{l}\text { Ratio of } \\
\text { benefits to } \\
\text { taxes }\end{array}$ & $\begin{array}{l}\text { Per capita } \\
\text { difference } \\
\text { (dollars) }\end{array}$ \\
\hline All & 375 & 430 & 0.87 & -203 \\
\hline \multicolumn{5}{|l|}{ Age } \\
\hline Under 18 & 3 & 1 & 2.00 & 18 \\
\hline $18-29$ & 4 & 74 & 0.05 & $-1,575$ \\
\hline $30-49$ & 19 & 248 & 0.08 & $-2,736$ \\
\hline $50-64$ & 49 & 97 & 0.50 & $-1,231$ \\
\hline $65+$ & 301 & 10 & 29.63 & 8,981 \\
\hline \multicolumn{5}{|c|}{ Family Income Excluding Social Security Benefits Relative to Poverty Threshold } \\
\hline Less than 50 percent & 125 & 1 & 89.64 & 3,930 \\
\hline 50 to 100 percent & 48 & 6 & 7.49 & 1,837 \\
\hline 100 to 200 percent & 71 & 31 & 2.28 & 882 \\
\hline 200 to 300 percent & 43 & 52 & 0.82 & -218 \\
\hline More than 300 percent & 88 & 339 & 0.26 & $-1,933$ \\
\hline \multicolumn{5}{|l|}{$\operatorname{Sex}$} \\
\hline Male & 184 & 272 & 0.68 & -660 \\
\hline Female & 191 & 158 & 1.20 & 233 \\
\hline \multicolumn{5}{|l|}{ Region } \\
\hline Northeast & 77 & 87 & 0.89 & -187 \\
\hline Midwest & 90 & 105 & 0.86 & -233 \\
\hline South & 137 & 140 & 0.98 & -30 \\
\hline West & 70 & 98 & 0.71 & -451 \\
\hline \multicolumn{5}{|l|}{ Race } \\
\hline White & 334 & 372 & 0.90 & -168 \\
\hline Black & 33 & 38 & 0.87 & -147 \\
\hline Asian and other & 8 & 20 & 0.38 & -935 \\
\hline \multicolumn{5}{|l|}{ Hispanic-status } \\
\hline Non-Hispanic & 357 & 397 & 0.90 & -166 \\
\hline Hispanic & 18 & 33 & 0.53 & -487 \\
\hline \multicolumn{5}{|l|}{ Education } \\
\hline Less than high school & 108 & 30 & 3.57 & 1,616 \\
\hline High School & 134 & 119 & 1.13 & 172 \\
\hline More than high school & 132 & 281 & 0.47 & $-1,093$ \\
\hline
\end{tabular}

Source: Author's calculations from the March 1999 Current Population Survey. OASDI benefits and taxes are scaled to match aggregate levels for 1998 as reported in Board of Trustees (2001). OASDI taxes include both employer and employee share. For children under 18, the family head's education level is used for the tabulation by education. 


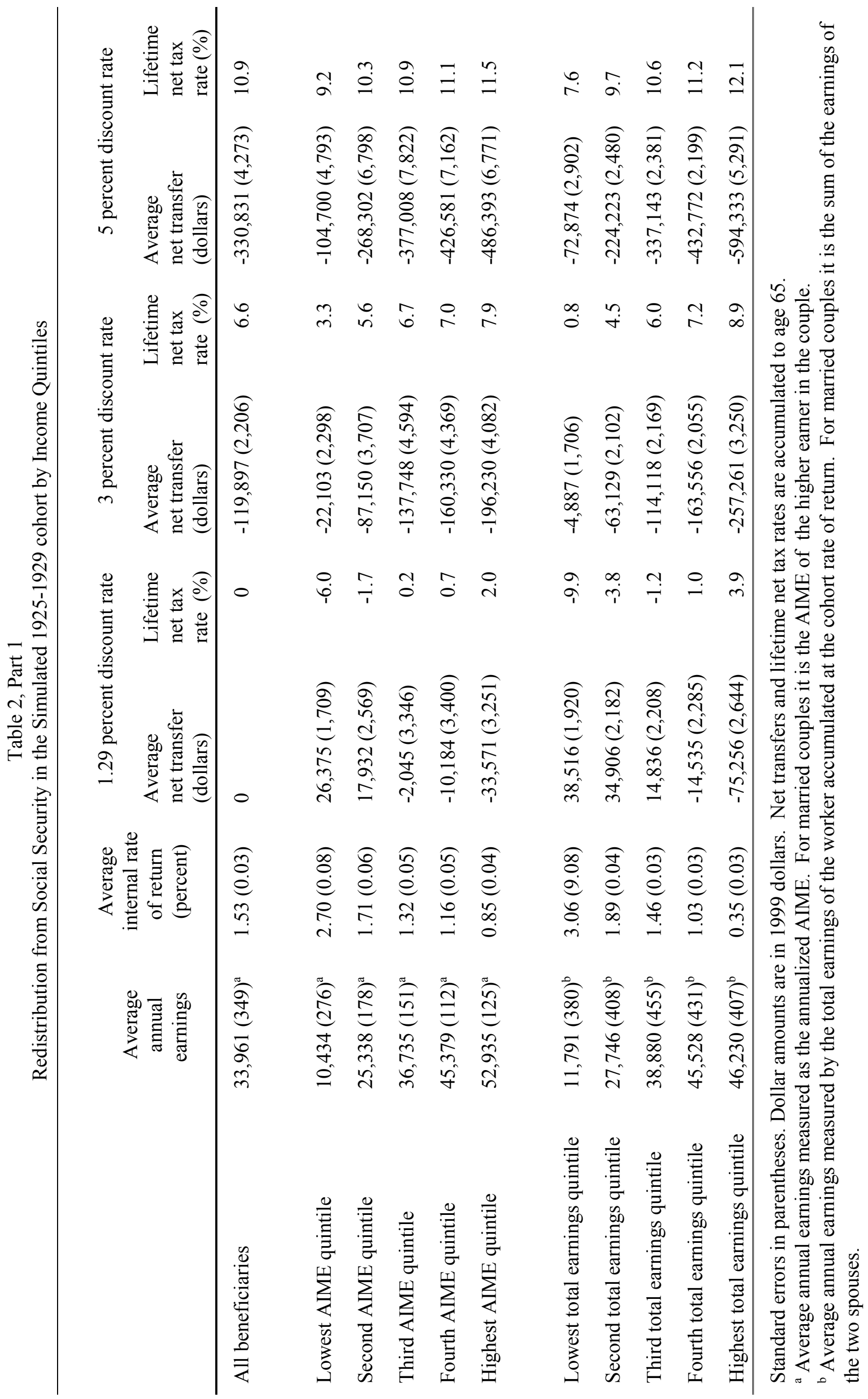




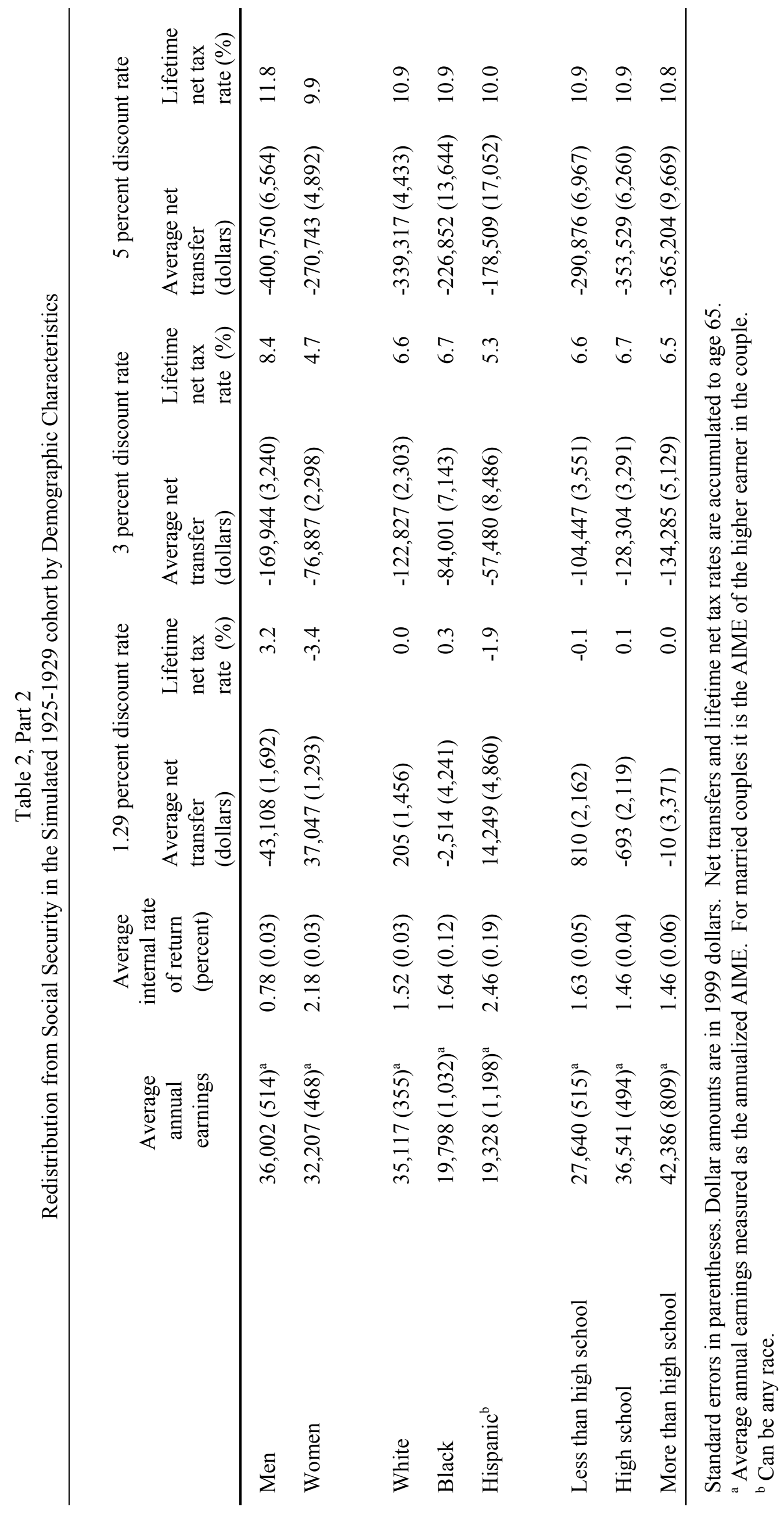




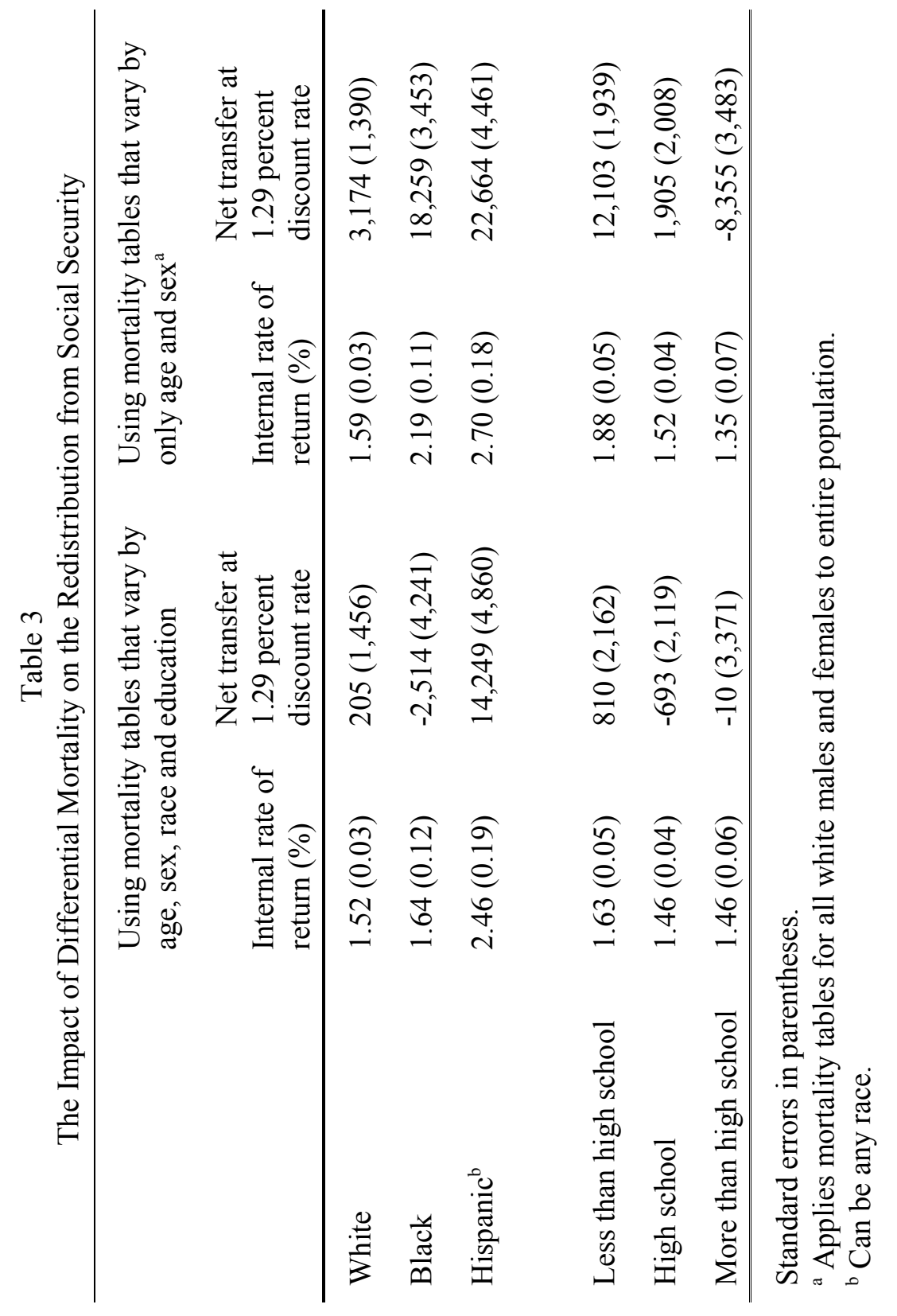




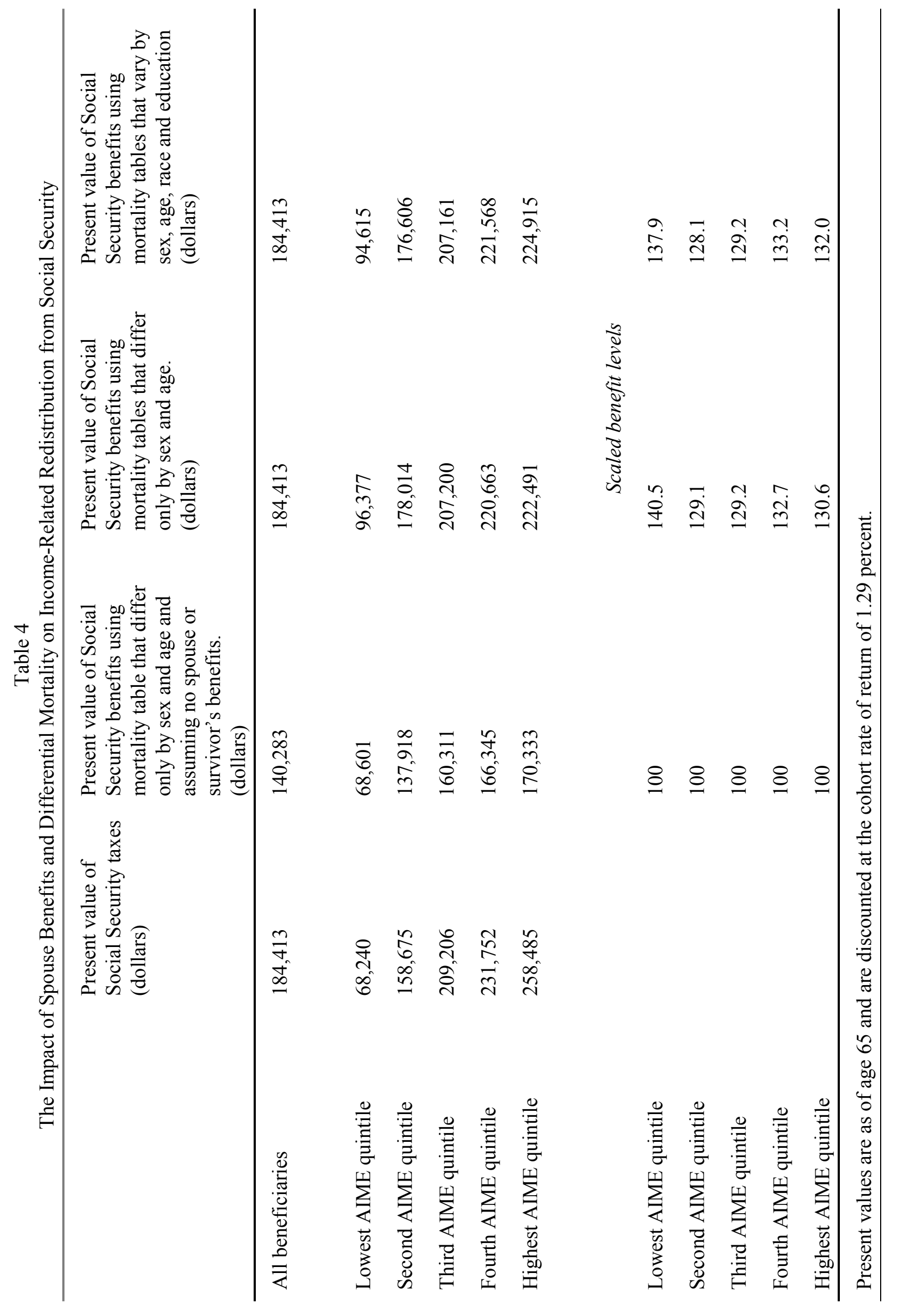




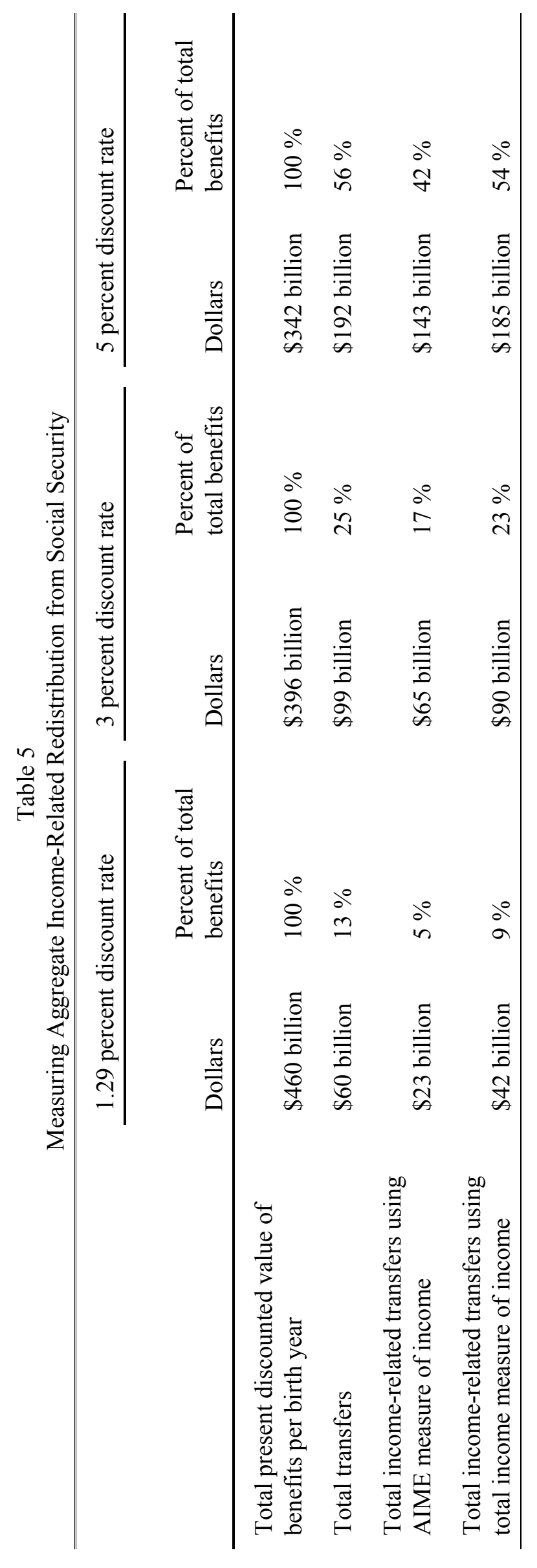




\section{Figure 1}

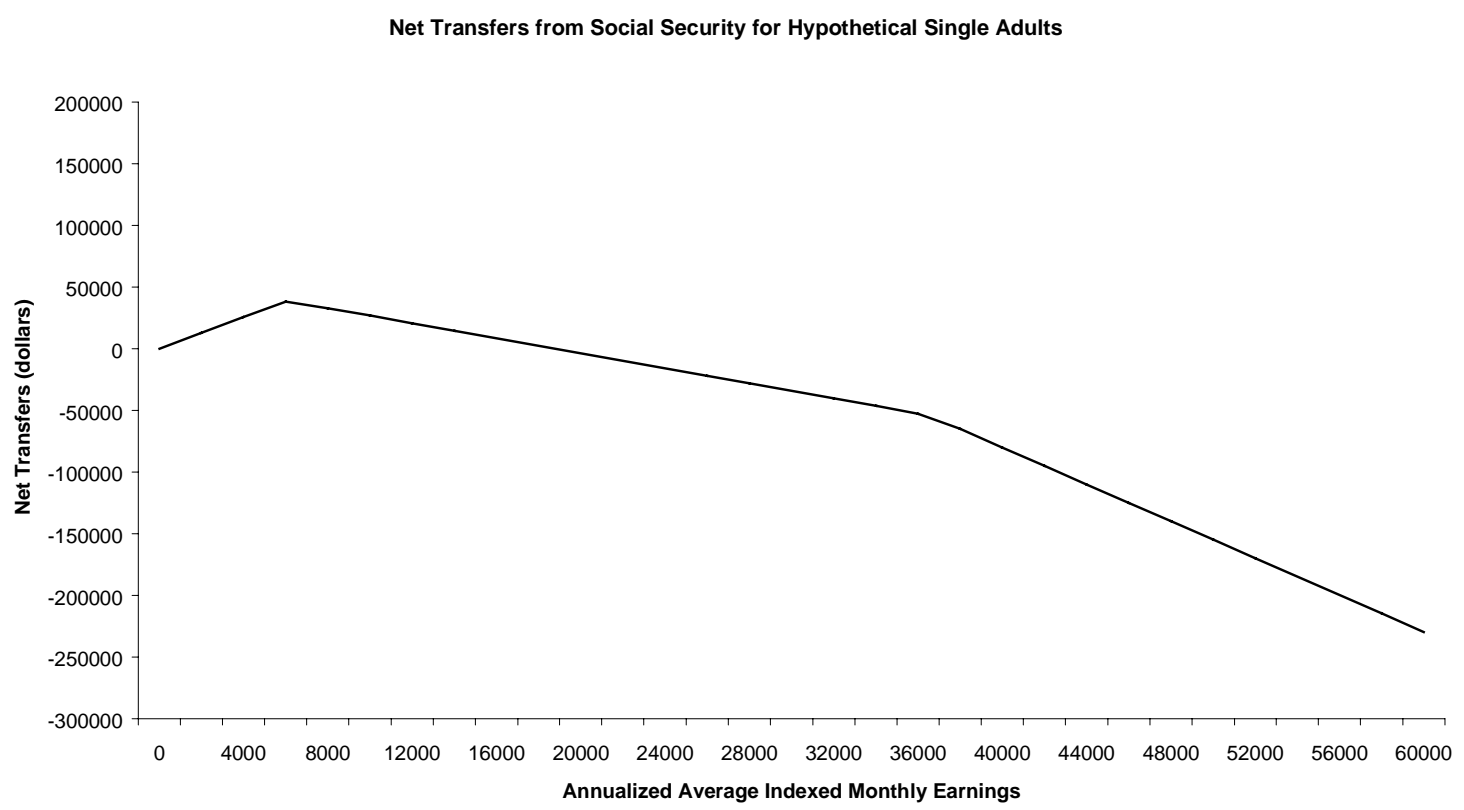


Figure 2

Net Transfers from Social Security by Income, All Individuals

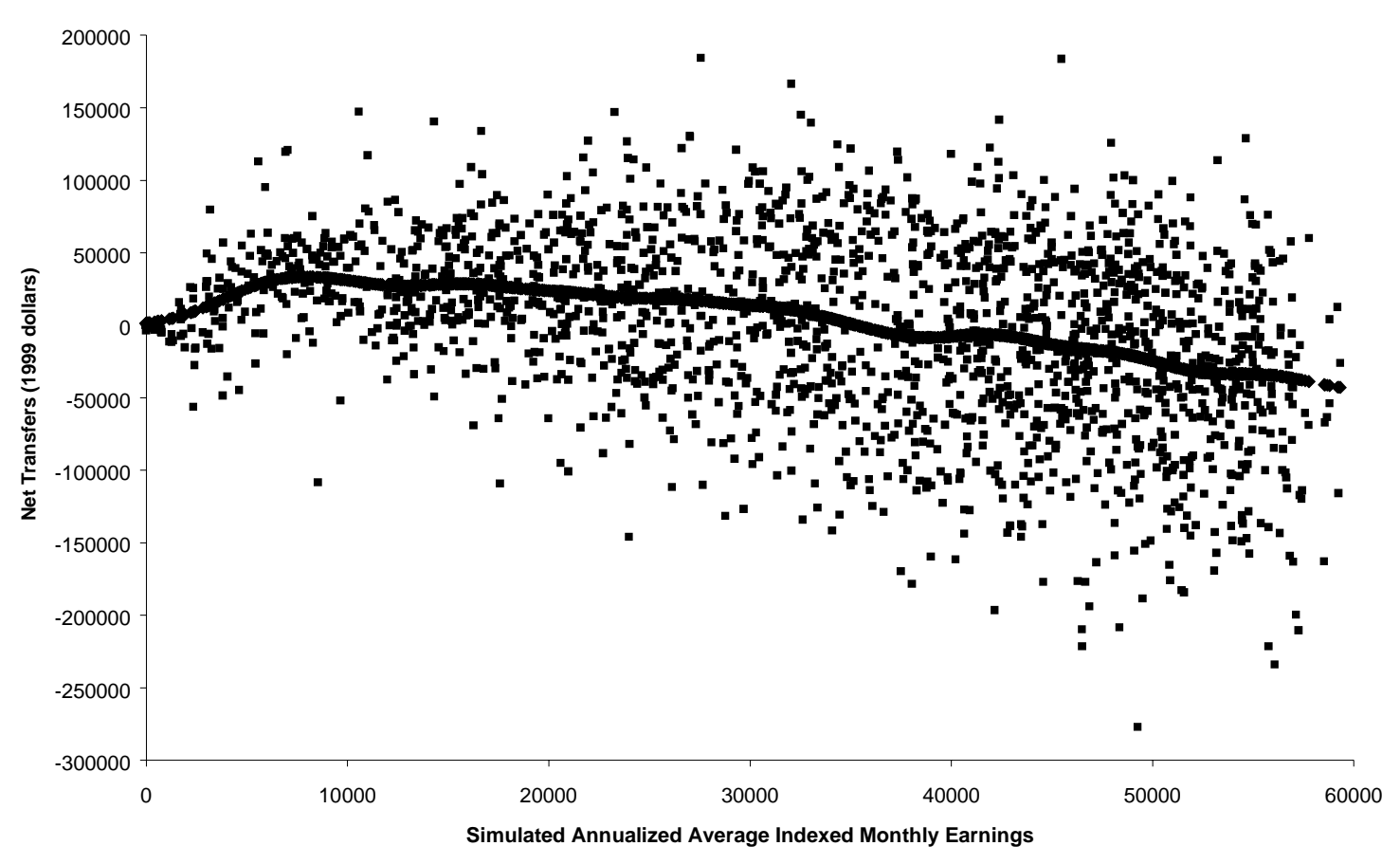

The points have been randomly jittered to preserve confidentiality. 
Figure $3 a$

Net Transfers from Social Security by Income, Males

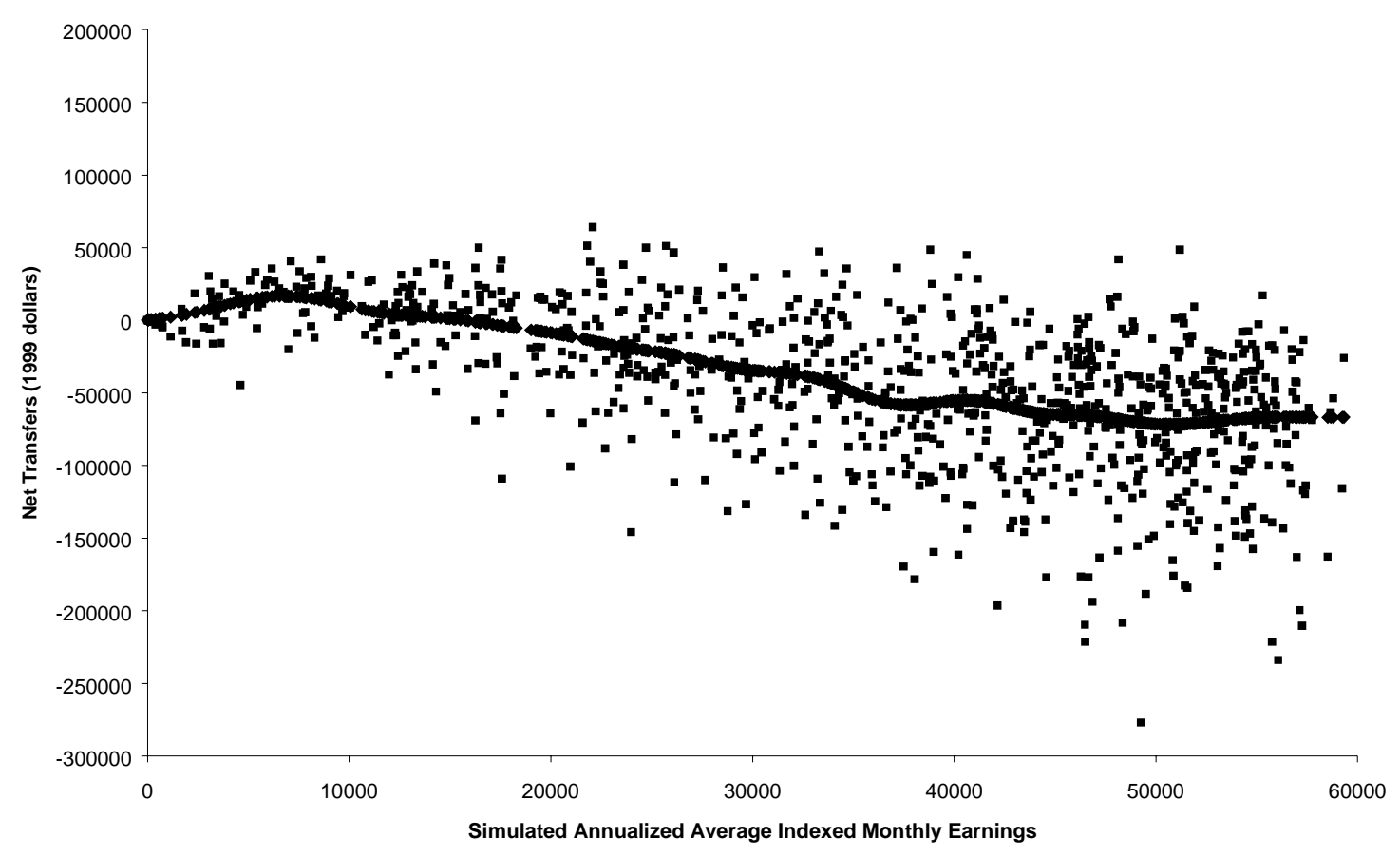

The points have been randomly jittered to preserve confidentiality. 
Figure $3 b$

Net Transfers from Social Security by Income, Females

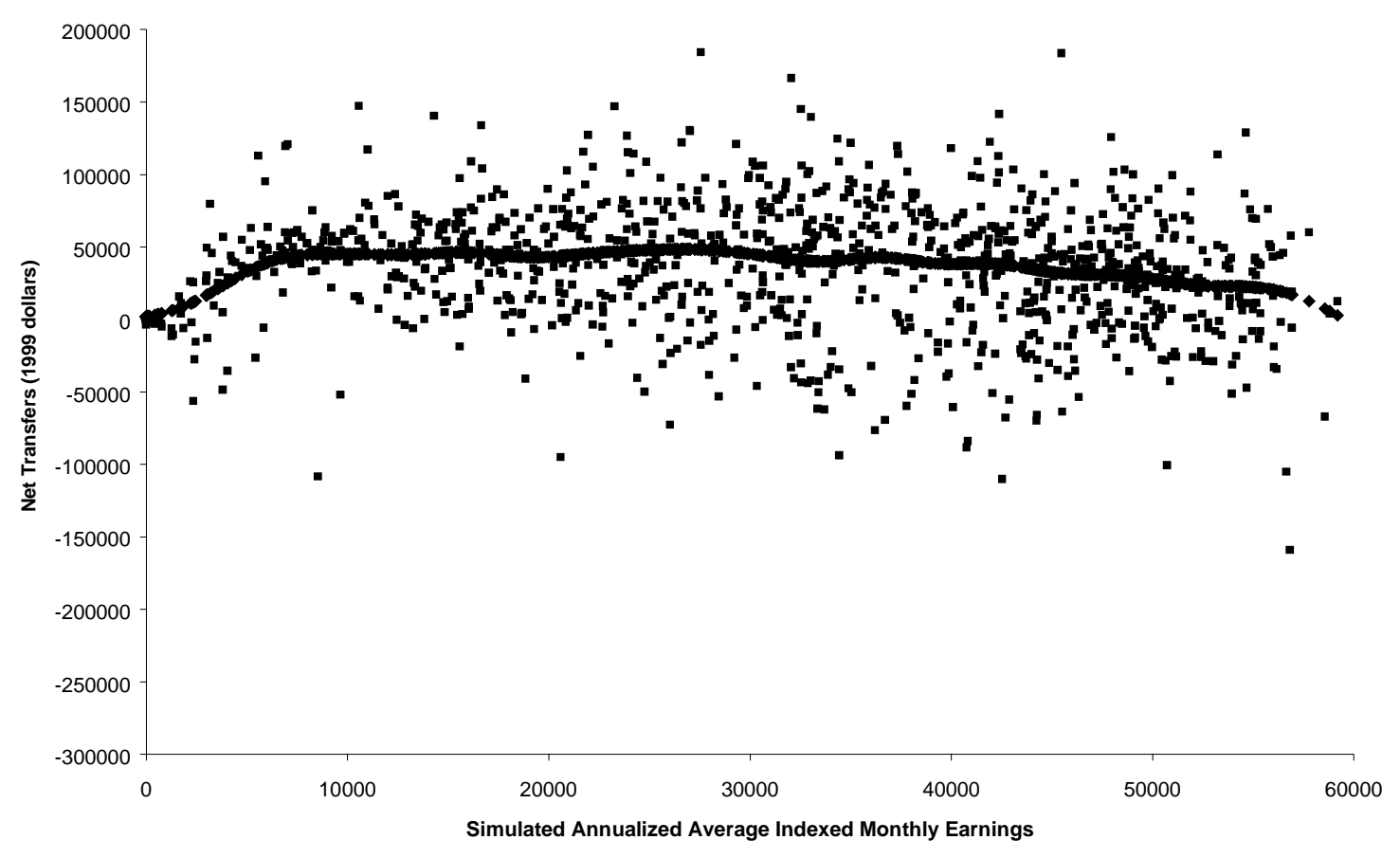

The points have been randomly jittered to preserve confidentiality. 
Figure 4

Internal Rates of Return from Social Security by Income

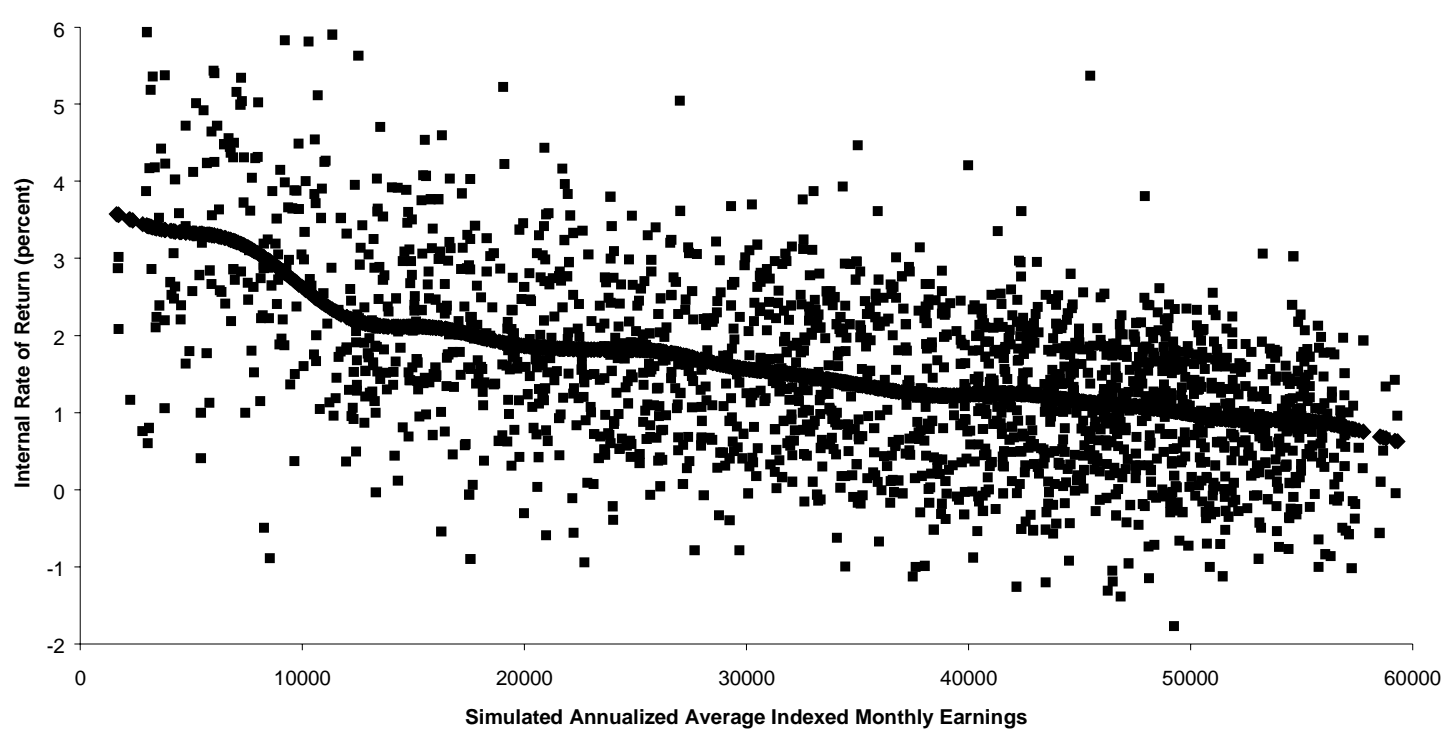

The points have been randomly jittered to preserve confidentiality. 
Figure 5

Net Transfers from Social Security by Income, All Individuals

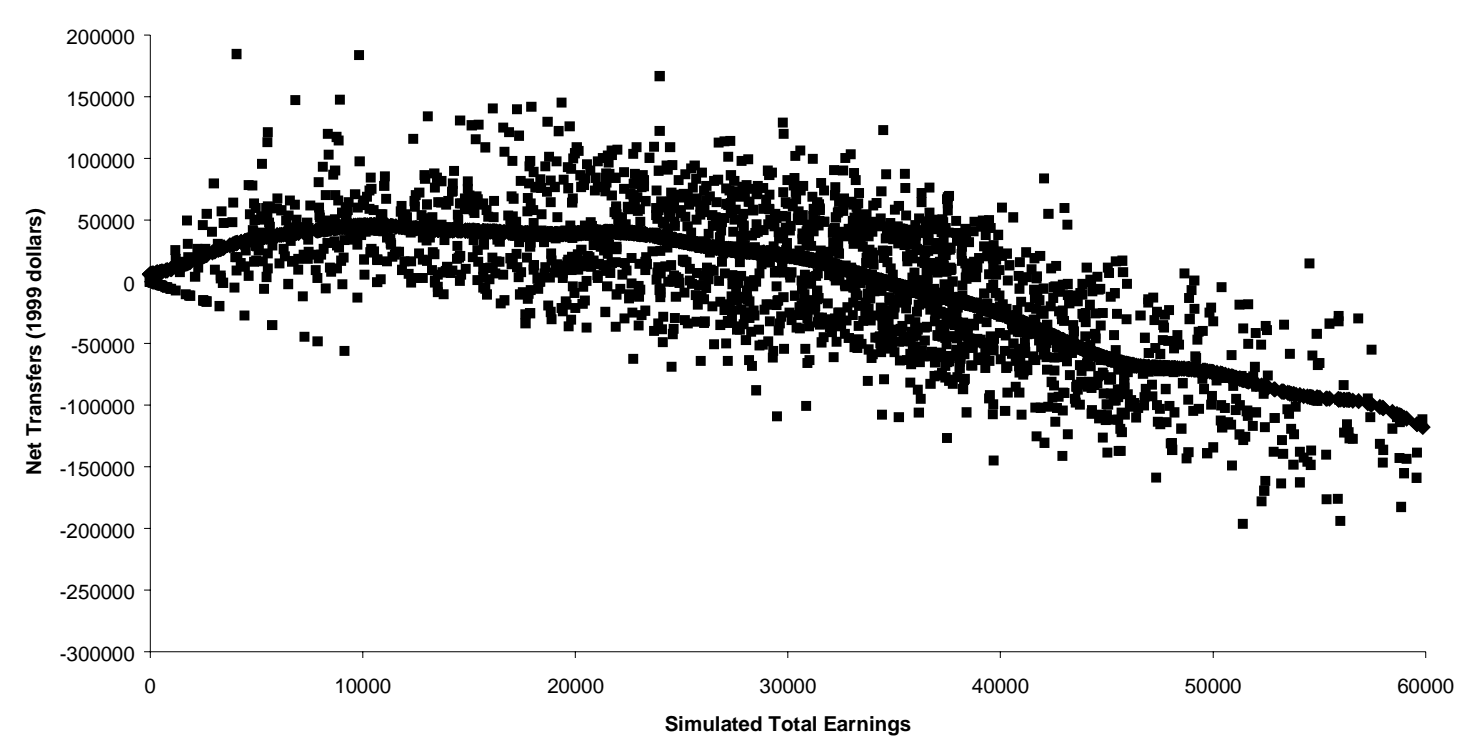

The points have been randomly jittered to preserve confidentiality. 